\title{
Female Agency and Subjectivity in Some Selected West African War Novels
}

\author{
Juliana Daniels* \\ University of Education, Winneba, Ghana
}

*Corresponding Author: Juliana Daniels, University of Education, Winneba, Ghana

\begin{abstract}
This article evaluates the subjectivity and agency of African women in Adichie's Half of a Yellow Sun, Purple Hibiscus, Pede Hollist's So The Path Does Not Die and Elma Shaw's Redemption Road. The discourse in the article is located within the framework of critical studies on third world women and in the locus of African Womanism. Within this framework, the discursive is constructed in the ambits of persistent distortion of the realisms of African women in literary works which impetuses the imperative need for a shift in literary paradigm in a way that projects the existentialisms of African women to reflect their trials and triumphs and navigation strategies. Consequently, the article examines how some third generation West African novels depict the agentic individuation of African women in their novels. The paper concludes that there is an emerging breed of African women who are capable of agency and subjectivity.
\end{abstract}

Keywords: Hegemonic Feminism, Women, Womanism, Agency, Subjectivity, African Literature

\section{INTRODUCTION}

Feminism as a movement has been around for the last four decades with the singular motive of advocating gender awareness. According to Showalter (1985, p.3) cited in Akung (2007, p.24), because men and women have different perspectives and interpretation of texts, it is important that women have their own voice regarding issues pertaining to women:

... feminist criticism developed as part of the international women's movement ... feminist criticism has shown that women readers and critics bring different perceptions and expectations to their literary experience, and has insisted that women have also told important stories of our culture.

From the above, it is not merely sufficient that women write. It is also imperative that they interpret not only their own stories but also stories written about them by men. This is one way of curbing biases against women in literature hence the production of this paper. A gendered interpretation of literary texts ensures that society in general has access to a fair representation of women as the distorted images of women are revealed and critiqued. Another resultant effect of gendered interpretation of literary texts is the highlighting of female writers and the aesthetics of their art. According to Akung (2007, p.25), "feminist aesthetic logically celebrates female consciousness"

Generally, despite the many years of tireless efforts put in by many writers such as Bessie Head, Ama Atta Aidoo, Ammato Darko, Elaine Showalter Chimamanda Ngozi Adichie, Elma Shaw and Pede Hollist amongst others, to propagate gender consciousness, gender inequality persists. Laqueur (1986, p.18) argues that there is rather a heightening of gender inequality where women remained 'incommensurable' to men. Superstitions, stereotypes and traditions that uphold male superiority over females persist. Fwangyil (2011) affirms this by indicating that indeed many people generally perceive women in general, including African women, as compliant, flaccid and scrawny in predominantly male cultures. She however asserts that irrespective of this general opinion about women, in her view, the new crop of African women in Adichie's Purple Hibiscus are self-assured in a way that deflates this age-old acuity:

Women are generally regarded as docile, passive and weak in most male-dominated societies. In this novel [Purple Hibiscus], the women work hard to debunk this age-long myth by asserting themselves and proving their mettle, regardless of the obstacles they face (p.271) 
Fwangyil's finding above drives the discourse in this paper. This paper therefore investigates whether there are other women in literature who defy the stereotypical description of African women as often flaccid and subjugated. The enquiry is carried out through the examination of African women's agency and subjectivity in four purposively selected West African war novels; Chimamanda Ngozi Adichie's Half of a Yellow Sun and Purple Hibiscus, Pede Hollist's So The Path Does Not Die and Elma Shaw's Redemption Road. The rationale behind choosing these texts include the fact that in most African countries self-governance after independence has come with many huddles. One such difficult hurdle is achieving non-violent resolution of conflicts. Conflicts undoubtedly exacerbate incidents of hyper-masculinities against women. Sierra Leon, Liberia, Nigeria, Ivory Coast, Guinea are few of the countries that have seen some bloody conflicts. In other volatile countries where conflicts have not broken out yet, the high political tension in the country often seeps down into the very fabric of society, the home. Thus domestic violence and war related gender brutalities against women is a common experience for many women in West African. The situation is similar to what pertains in many other African countries such as Central African Republic, South Africa, Burindi, Kenya etc. The widespread nature of African women's conflict related experiences of violence makes the selected novels amply representative. It is in such dire war scenarios as depicted in the selected novels that I seek to examine how African women's agency and subjectivity evolve.

The rationale behind the choice of these specific novels is also stemmed in the novels' ability to depict both the quotidian trials and triumphs of contemporary African women. The unadorned portrayal of the heroisms and challenges of African women as depicted in the selected novels opportune the explication of African women's potentialities in context. The illumination of African women's agency would rectify global knowledge about Africa and her women. According to Bressler (1994, p.103) cited in Akung (2007, p14) the goal of feminism "is to change the degrading view of women" in society. Hence any effort to alter the distorted image of some group of women in society is within the praxis of feminist criticism. The discussion in this paper is also motivated by the fact that portrayal of the assertiveness of African women in this paper is vital to the re-orientation of African women on their own potentialities. This discourse would also educate and encourage African women to explore their world and continue to manipulate it in a way that ventures their womanist instincts; seeking equality for themselves as harmonious coexistence with their communities, which include men. In addition, I believe that there is an imperative need for global re-theorization of third world women in general and African women in particular. This is the only way African women can be fairly represented in literary discourses. I am therefore hopeful that the discussion in this paper will spearhead a crusade aimed at re-cast the generally denigrated image of African women in global literary discursive.

Let me emphasize here that to ensure that the arguments put forth in this paper are very well comprehended, it is worth warranting that the two key ides, subjectivity and agency, used to foreground the discourse in this confab are well understood. Subjectivity, in this paper, is presented as the ability to produce knowledge. The generic 'subject' is used here as a noun to mean selfdetermining agency and not as a verb that refers to the process of being defined and controlled by external forces (Chakravarty, 2007).

\subsection{So The Path Does Not Die: The story}

Hollist's So The Path Does Not Die (2012) highlights migration, the challenges of belonging and the need for ingenuity. It is a reflection of the contestations of the internally, externally, economically and war displaced women in Sierra Leonean during the armed conflict that spanned between 1991 and 2002. It is also a dossier on Finaba, the central character's growth and development in age, womanist consciousness and subjectivity. Fina's story begins with her naïve crave for initiation to adulthood which involves circumcision (p.3). Her parent's relocation from the village, Talaba, to the city, Freetown, (p.14) opens another chapter of her life. In the city, she finds herself in the segregated minority clutch of Fulas amidst the majority group, Krios (p.15). The demise of her father that leads to her time with the foster family, the Heddles, signify another phase of priming in Fina's life where she learns to endure and circumvent oppression (p.17). Her college experience also augments her womanist subjectivity in the way it builds her resistance against suppression (p.50). This trait is further strengthened when Fina moves to America. There, she educates us on female genital mutilation (FGM) in a spat with Cammy, her fiancé. The two argue extensively about female genital mutilation and African women's need to belong, and the need to share with others by reaching out to 
the needy and the war and culturally distressed (p.210). Fina climaxes her agentive evolution through her altruistic services when she returns home from America to war shattered Sierra Leone (p.280), against the will of Cammy her fiancé (p.226).

\subsection{Redemption Road: The story}

Like Fina who is privileged in Holist's war novel, Bendu Lewis is also centralized in Elma Shaw's Redemption Road (2008). The novel is set in the epoch of the Liberian war that sparked in 1980 with the assassination of President William R. Tolbert, Jr., until 1996. Bendu Lewis opens the story as a muted young girl and ends it as one who discovers her voice and strength (p.10). When Bendu is conscripted by the rebels at the start of the war, she is beaten to cower (p.59). Throughout her life in the Deluma Camp, where the rebels hold her and others, Bendu learns to endure and also to circumvent oppressive war experiences (p.120). Bendu's exit from the camp marks a transformational phase of her journey to selfhood. She returns to Monrovia to make good use of her war time experiences. Her bold confrontation with Cobra leads to the latter's death (p.176). Her control of her sexuality in her relationship with Calvin Daniels (p.18) and her ability to educate, mobilize funds and to lead other women to run the outfit that helps many war traumatized women to recover (p.22) epitomizes her ultimate womanist maturation and her eccentric valour.

\subsection{Half of a Yellow Sun: The story}

Adichie's Half of a Yellow Sun (2007) set in eon of the Biafra war in Nigeria, pivots on the lives of twin sisters Olanna and Kainene. Like Bendu and Fina mentioned earlier, the lives of the twins are presented in a continuum beginning with their return to Nigeria from studies in London to their philanthropic contributions to the Biafra war. They open the story with a strong show of selfhood by insisting on their life paths against the dictates of their parents (p.31). In Nsukka, where Olanna chooses to live her life with Odenigbo her fiancé, Olanna receives lessons of African womanhood (marriage, motherhood and external family tolerance) through her unpleasant encounter with Odenigbo's mother (p.104). The experience toughens her and empowers her to firmly guard her household through the Biafra war (p.392). By the end of the war, Olanna emerges as a strong woman who has absolute control over her family's welfare.

Meanwhile, Kainene, as a woman who does not marry or have children, exhibits knowledge and intervention by successfully running her parents businesses (p.81) and creating a support base for people displaced by the Biafra war (p.318). Kainene's kind of feminist agency and individuation is unique in the sense that by going over enemy lines to find aide for the displaced, she puts her life in jeopardy (p.433). Her sense of womanist commitment to the wellbeing of her community goes beyond the mere refutation of hegemonic literary critics' denial of African women's agentic potentialities. Instead, it emphasizes African women's often taken-for-granted exceptional potentialities.

\subsection{Purple Hibiscus: The story}

In Adichie's novel, Purple Hibiscus (2006) the effect of colonial religious residue and post-colonial political tumult on the nation and the family, and the indispensable role of women is underscored. Ifeoma is a strong woman who is widowed with three children (p.83). In the absence of her husband, she manages to bring up her children well. When the corruption that plagues the Nigerian society surfaces in Nsukka University where she teaches, Ifeoma voices her disapproval (p.226). She is consequently threatened by the school authorities with expulsion but she does not betray her fears (p.227). The minute she finds the conditions at university and Nigeria unbearable (p.234), Ifeoma plans and executes the immigration of her family to America where she is able to give them a better life (p.304).

Ifeoma's brother Eugene is very wealthy but abusive and stingy towards her. The political turmoil in the Nigerian state takes a toll on him and his publishing house (p.255). He vents his frustration by becoming even abusive towards his wife and children (p.156). He physically abuses his wife, Beatrice, and children, Jaja and Kambili (pp.153, 253) and refuses to take care of his father in the village because he is 'heathen' (p.89). Eugene's heavy-handedness on Beatrice, his wife, and Jaja and Kambili, his children leaves them morbid in fear (p.89). Compared to Ifeoma and her children who are buoyant and expressive, Beatrice and her children are rather timid and unassertive.

However, Ifeoma orchestrates the womanist transformation of Beatrice and her children (p.257). Through encouragement and sensitization, she gets Beatrice to understand that a wife has the right to 
a life that is free of abuse and humiliation (p.83). Ifeoma, as a result, empowers Beatrice. The latter acquires the courage to undertake the radical decision of poisoning her husband to death (p.294). Jaja and Kambili's experiences with Ifeoma's children also enlighten and embolden them (p.153). Jaja becomes assertive by positively defying his father's tyrannical orders (p.262). On the part of Kambili, her maturation manifests in her ability to speak her mind and defend her opinion (p.177) as she demonstrates cheerfulness (p.273). Both Ifeoma and Beatrice end the story by prevailing over patriarchal subjugation and ensuring the protection and wellbeing of their children (p.312).

\section{THEORETICAL APPROACH}

The crust of the discussion in this paper rests on my interest in tracing the transmogrification of African women from novices to doyens. This is integral to my effort to demonstrate that these women are capable of agency and subjectivity irrespective of the subjugating inhibitions that frustrate their efforts to be agentic. To better achieve my aim for this discursive, I situate my discussion within the framework of African feminism. African feminism allows me to examine how the authors of the selected novels typify African women in order to counter hegemonic derogatory postulations about these women.

Of the many shades of African feminism, I identify Chikwenye Ogunyemi's African Womanism as an appropriate framework for the praxis in this discourse. Ogunyemi (1985) delineates her concept of Womanism as a philosophy that:

"celebrates black roots [and] the ideals of black life, while giving a balanced presentation of black womandom [and] concerns itself as much with the black sexual power tussle as with the world power structure that subjugates blacks." (p.13)

From the excerpt above, the womanist in Africa does not deny her roots and the challenges of her circadian lives. Instead she embraces her realities whiles fashioning out strategies of exit or navigation. The intrepidness of womanists speak to their potentialities as evidence of their idiosyncrasies and agentic capabilities. Womanist's interpretation of African women's lives provides a vital avenue for the demonstration of the challenges African women face and the pricelessness of their triumphs.

Ogunyemi (1985) further argues that:

Womanism, with its myriad manifestations, is therefore a renaissance that aims to establish healthy relationships among people, despite ethnic, geographical, educational, gender, ethical, class, religious, military and political differences. (p.123)

Womanism as indicated above advocates gender cooperation for harmonious co-existence between the sexes and amongst all people. However, one significant flaw of this theory is its failure to adequately account for the triumphs of African women. Eaton (2004) adds that one of the objectives of Womanism is to advocate issues that enhance the lives of not only Black women, but black men and other clutches that have been endangered by percipience or ineffectualness. Thus in this chapter, I offer a discursive on Womanism as a gendered habitus of African women that highlights African women's contestations and accomplishments. Womanism, as used in this context recognizes African women's relish in seeking their interest with cognizance for the benefit of all, including men. Consequently, I pay attention to how the womanist characteristics of African women in Chimamanda Ngozie Adichie's Half of a Yellow Sun and Purple Hibiscus, Elma Shaw's Redemption Road and Pede Hollist's So The Path Does Not Die connects with their physical, cultural and middling social lives. In the process, from the lens of womanism I bring to the fore how African women's subjectivities evolve in their lived realisms.

A review of existing literature shows that Ogunyemi's African womanism provides the framework for effective analysis of African women's lives because it unequivocally rejects literary discourses portray African women as incapable of assertiveness and contribution to the growth and development of humanoid. Ruth $(1990$, p6) describes a womanist as usually referring to one with "outrageous, audacious, courageous, or willful behavior. Wanting to know more and in greater depth than is considered "good" for one". She adds that it also connotes one "trying to be grown, responsible and serious". Ogunyemi (1985) indicates that her concept of an African womanist is one that accepts men as men but does not have to be like them. Instead, she adds, a womanist creates stability in her 
complex life. This purview emphasizes the competence and individuation of the womanist. It is therefore from Ogunyemi's womanist perspective that I examine the representation of African women's subjectivity and agency in Chimamanda Ngozi Adichie's Half of a Yellow Sun and Purple Hibiscus, Pede Hollist's So The Path Does Not Die and Elma Shaw's Redemption Road.

A further appraisal of literature on the imaging of African women's assertiveness in literary discourse shows that the erroneous presentation of African women is pervasive. Fonchingong (2006) posits that some prominent male African writers can be mentioned as evidence of how writers fixate African women in the peripheral through homogenization and reductionism of women's potentialities:

Chinua Achebe, Elechi Amadi, Wole Soyinka, Ngugi Wa Thiongo, and Cyprain Ekwensi in their literary mass are accused of condoning patriarchy, are deeply entrenched in a macho conviviality and a one dimensional and minimalised presentation of women who are demoted and assume peripheral roles (p135).

Fonchingong (2006), in the extract above, reiterates the problem this paper seeks to resolve in the sense that the pervasiveness of literary discursive that distorts the image of African women in global literature and the imposition of flawed notions of African women on global feminist thought is a far cry from the realisms of African women today. This paper therefore finds an urgent need for literary criticisms that debunk the flawed thought of African women as incapable of attaining subjectivity. Supporting men, children and other women, rescuing them and nurturing them are all often taken for granted activities performed by women, especially during war. These activities amount to the demonstration of the agency and assertiveness of African women.

\section{THE DISCUSSION}

The novels selected for this discussion present how African women execute assertiveness and power through knowledge, hard work resistance of neo-colonialist capital repression. African women in the novels show that if given a chance, they are capable of demonstrating agency and forcefulness. For example, in Adichie's Purple Hibiscus, Ifeoma is threatened by the mannish university authorities when she endeavors to voice her disapproval of the monopoly of leadership on the national front and in the university (p.227). However, this does not shut her up. She shows assertiveness by insisting on her right to speak (p.235). In addition she continues to instigate her students to resist the university's hegemonic administration saying: "We cannot sit back and let it happen" (p.227). By making an impact on her university community, Ifeoma becomes Adichie's proxy for the validation of her disagreement with voices like Grosz (1994) and their avowal that African women are trapped in coercion and passivity, and are incapable of interventionism. As a lecturer, Ifeoma epitomizes African women's aptitude for creating and sharing knowledge for national development. The attempt by the university authorities to shut her up is tantamount to capitalist repression stemmed in patriarchal idiosyncrasy and pseudo colonial despotism.

There is also evidence, in Half of a Yellow Sun, of the fact that when given the opportunity, African women can exhibit subjectivity and agentic competence. In the story, when Adichie introduces Kainene to spearhead African women's renaissance in the capitalist world, we have men like Chief Okonji reacting with a shudder by asking: "So Kainene will manage the cement factory?" (p.31).The evidence of sarcasm is registered in the jingoistic nature of Chief Okonji's question. He seems to suppose that females are incapable of competing successfully in the patriarchal capitalist world: "his [Chief Okonji] face seemed to melt, folding in on itself. Then he turned and asked, too brightly" whether Kainene will be handed her father's business (p.31). Adichie registers a loathing for men who perceive women as incapable of agency and selfhood through Kainene's snappy and acerbic response to Chief Okonji's sarcasm:

Kainene looked Chief Okonji right in the eyes, with that stir that was so expressionless, so blank that it was almost hostile. 'What about me, indeed?' She raised her eyebrows. 'I too will be putting my newly acquired degree acquired degree to good use. I'm moving to Port Harcourt to manage Daddy's business there'. (p.31)

From the above, Kainene clearly shows her disapproval of Chief Okonji's under-estimation of her capabilities. Chief Okonji's inability to fathom a female in a male dominated business world is further expressed in his 'sincere' admiration, though with a stereotypical connotation purposed to deride Kainene's agency and confidence when he comments: "Whoever said you lost out by having twin 
daughters is a liar" (p.31). Chief Okonji's association of Kainene with manliness attests to Kainene's ability to break into the highly guarded patriarchal public sphere of business and politics in postcolonial Nigeria. It is justifiable that Kainene is indifferent to Chief Okonji's supposed admiration of her tenacity. After all, womanists do not seek to be like men hence in this instance, I presume that Kainene views Chief labelling her 'boyish' as with a derogatory connotation that is meant to discourage her. Major Okonji's comparison of Kainene to a male child is also Adichie's effort to carp the stereotypical African culture that privileges male children over females. Kainene's successful win of business contracts thus emphasizes the point that African women are capable of capitalist agency and therefore deserve the opportunity to accentuate their subjectivity and potentialities as Kainene reiterates below:

I've just got the contract to supply army boots for the battalion in Kaduna...the man in charge was Igbo, and Madu said he was keen to give the contract to his fellow Igbo. So I was lucky.

And he is asking only for five percent cut (p.81)

Kainene's manipulation of the highly masculine world of business and politics is therefore Adichie's effort to challenge and quash masculine reign in the capitalist world. It also is her attempt to emphasize that if given the opportunity as Kainene is, African women have the capacity to influence their society. As a womanist, Kainene asserts her agentic 'self' by fighting to be her desired kind of woman. Kainene's subjectivity evolves as she successfully invades a 'supposedly' male territory by navigating what Kandiyoti (1993) cited in Makokha (2014) refers to as 'public patriarchy' under 'neopatriarchy':

Private patriarchy is based on the relative exclusion of women from arenas of social life other than the household and the appropriation of their services by individual patriarchs within the confines of the home. Public patriarchy is based on employment and the state; women no longer excluded from the public arena but subordinated within it. More collective forms of appropriation of their services supersede the individual mode of private patriarchy ... the twentieth century has witnessed a major shift from private to public patriarchy (p.377)

The above is an indication that for African women to be able to meandre the curves of public patriarchy they must show competence and depict the potential to attain subjectivity. From the African womanist perspective, Adichie therefore denounces literary texts that accentuate African women's impotencies to the detriment of the competencies of other women such as Kainene. Kainene thus becomes a medium by which Adichie demonstrates African women's ability to attain agency and subjectivity.

Another means by which Kainene exerts her subjectivity is when she decides to date Richard, an expatriate, to the disapproval of post-colonial Nigerian Igbo society as Major Udodi suggests below:

...our women who follow white men are a certain type, a poor family and the kind of bodies that white men like... Fantastically desirable bottoms...the white men will poke and poke and poke the women in the dark but they will never marry them... they will never even take them to a good place in public. But our women will continue to disgrace themselves and struggle for the men so that they will get chicken-feed money and nonsense tea in a fancy tin. It's a new slavery, I'm telling you, a new slavery. But you are a Big Man's daughter, so what are you doing with him? (pp. 80-81)

Major Udodi is a friend to Madu and Madu is Kainene's childhood friend. The above intercourse occurs when Madu and Udodi visit Kainene. It is during their interaction that Udodi expresses a patriarchal typecast that precincts African women within masculine dictates of who an African woman can date. However, Kainene defies him and his stereotypical normative that would otherwise grip her in the jacket of traditionally oppressed African women. Kainene finds Udodi's ranting in the excerpt above very disconcerting however, she levers the humiliating situation with grace that even mesmerizes Richard, her white boyfriend (81). Her self-control, strong will, decisive and persevering spirit makes her a powerful woman who has clear knowledge of what she wants in her life. Kainene, without a qualm, has complete control over her sexuality and her 'selfhood'. This is how she exhibits subjectivity; being a strong woman with the ability to exercise her rights in her own right. It is this view of herself that enables her to trivialize Major Udodi's private patriarchal domination as a navigational strategy when she tells him, without mincing words, that her choice of lovers is none of Udodi's business. It is through her expression of selfhood that Adichie contests the edict that African women are passive and voiceless. 
Both Kainene and her sister Olanna show their agency by defying cultural stereotyping. However, whereas Kainene shows her subjectivity and potentialities by breaking the glass ceiling into the men's world of business in Chimamanda Ngozie Adichie's Half of a Yellow Sun, her sister, Olanna asserts her agency by resisting the objectification and commodification of her body. In the novel, Adichie denounces the familial commodification of the female body through Olanna's kick against her parent's arranged relationships: "She [Olanna] wondered, too, how her parents had promised Chief Okonji an affair with her in exchange for the contract" (p.32). Apparently, most of Olanna's father's business colleagues and politicians want to have sexual favours from Olanna, the beautiful daughter, before extending any business tenders:

'I just can't keep you out of my mind', Chief Okonji said again. 'Look you don't have to work at the ministry. I can appoint you to any board you want, and I will furnish a flat for you wherever you want'. He pulled her to him and for a while, Olanna did nothing, her body limp against his. She was used to this, being grabbed by men who walked around in a cloud of cologne-drenched entitlement, with the presumption that, because they were powerful and found her beautiful, they belonged together. She pushed him back, finally... Stop it Chief (p.33)

Surprisingly, Olanna's parents encourage this to the disgust of her Kainene:

Daddy literally pulled me away from the veranda so we could leave you alone with the good cabinet minister,...Will he give Daddy the contract then?... He didn't say. But it's not as if he will get nothing. Daddy will still give him ten per cent, after all. Ten per cent is standard, so extras always help. The other bidders probably don't have a beautiful daughter... The benefit of being the ugly daughter is that nobody uses you as a sex bait (p.35)

According to Makokha (2014, p.115), the intentions of Olanna's parents and their business partners amount to perceiving the beautiful African woman as an 'object'. Olanna will however, not agree to that. She asserts herself, knowledge and power by insisting on being with her boyfriend, Odenigbo, and living and working in Nsukka (p.31). As a result, she vehemently refuses to prostitute herself for her parent's interest. She also refuses to marry Igwe Okagbue's son as well as Chief Okaro's son, both from affluent homes (p.35). Generally, she refuses to be dictated to by her parents. This way, she emphasizes her 'selfhood' by successfully insisting on her right to choose her marriage partners. Both Kainene and Olanna are used as vehicles for the demonstration of the novel image of the new generation of African women; they do not only know their rights, they insist on them and they are irrepressible in their expression of subjectivity and agency.

Like Kainene and Olanna who show strength against subjugation in Adichie's Half of a Yellow Sun, Bendu also expresses strength and agency as a womanist in Elma Shaw's Redemption Road. For several months she is conscripted and trapped in the camp of the rebels during the war in the novel. However, when the war ends and she returns to Monrovia we see a different woman whose subjectivity evolves with each passing day. For instance, Bendu's fight for vengeance against Cobra when he resurfaces after the war is a womanist fight for justice for crimes committed against the female 'self' as she puts it: "You killed my cousin Orlando and killed the person I used to be...They deserve justice. We all do. No justice no peace" (p.101). Bendu's confrontation of Cobra adds up to her healing process but more importantly outdoors her strength and fearlessness. The closure obtained by the news of Cobra's death sets Bendu on the path to self -discovery: "I've made up my mind ... Terrance was right: Cobra is dead and I have nothing to fear anymore" (p.187). Her womanist subjectivity evolves as she shares her renewed hope and strength in the mantra: "What doesn't kill me... Will make me stronger!" (p.149). Thus as a an agentic womanist and a source of knowledge and strength for all the afflicted in PIP, Bendu knows she has to keep hope alive; hope that the bad days of war related crimes of rape and murder are all over; that life can get better with the days ahead (p.149).

Bendu's agency is also revealed in the bravery with which she is able to confess her wartime experiences. To a womanist, confession is also an admission of one's existential reality that can only be admitted to by the brave. Thus Bendu suggests that real closure to the horrors of the war begins with first making a confession of all that she experienced during the war (p.149). This includes Bendu's confession to her sister, Siatta and others about having a child with a rebel and how she had abandoned this child as she fled the camp. The deep sense of completeness that Bendu discovers with reconciliation with her daughter is summarized in her words: "My daughter May is home at last. I 
cannot describe the joy I felt when I first laid eyes on her... (p.216). Hence Bendu proves herself a strong woman, knowledgeable, resilient and a victor over Cobra who is presented as an effigy of female oppression (p.199).

Like Bendu, Ifeoma in Adichie's Purple Hibiscus is presented as a brave, knowledgeable and assertive woman who successfully helps a physically and sexually abused family to overcome their tyrant. The encapsulating fear in which Beatrice, Kambili and Jaja lived under the roof of Eugene (husband and father) is symbolized by the silent means by which the trio communicate as Kambili reminisces: "I lay in bed ... and let my mind rake through the past, through the years when Jaja and Mama and I spoke with our spirit than with our lips" (p.24).

Beatrice and her children's limitations to freedom as epitomized in the novel Purple Hibiscus are as a result of both overt and latent fear of Eugene's animosities against them (p.80).Christopher Ouma (2007) believes that the tension in Adichie's Purple Hibiscus is as a result of imperial impositions on the continent. To him Eugene's predicament is influenced by the load he carried. This load, according to Ouma (2007), comprises the effect of two main colonial imports; Catholicism combined with the kind of politics practiced in Nigeria at the time. The tension and suffering in the novel, he asserts, coexist with corruption, economic failure and military dictatorship. Even then, Ouma (2007) still blames Eugene for submerging himself into the frays of religion by embracing Catholicism and burying any other concerns beneath it (p.12). I therefore agree with Ouma (2007) when he argues that Eugene's behaviour makes political motivation of religion liable for the suffering of the Beatrice and her children in the novel. Hence overtly, the mother, Beatrice, and children, Jaja and Kambili, dread Eugene's use of physical force (p.161) whiles latently, they fear the extent of injure that they may incur as a result of brutal physical force on them (p.216). The morbid fear that engulfs the triad sets the stage for Adichie to demonstrate the agency of Ifeoma, Eugene's sister. As a womanist, Ifeoma sets out to save Beatrice and her children. Adichie sets Ifeoma apart as a gender equalizer. Ifeoma amply navigates her path around Eugene the tyrant. She exerts her womanist aptitude to save both males and females. According to the narrator, Ifeoma becomes a medium for the portrayal of female agency by providing Beatrice and her children with a family setup in Nsukka that teaches them to be self-reliant, forbearing and yet both strategic and courageous enough to resist Eugene's abusiveness:

Nsukka started it all; Aunty Ifeoma's little garden next to the verandah of her flat in Nsukka began to lift the silence. Jaja's defiance seemed to me now like Aunty Ifeoma's experimental purple hibiscus: rare, fragrant with the undertones of freedom, a different kind of freedom from the one the crowds waving green flags ... Freedom to be, to do (pp.23-4)

To achieve the freedom of Beatrice and her children from oppression, Ifeoma demonstrates subjectivity by first insisting that her abusive brother's children come to spend some time with her own family in Nsukka (p.85). As an agent of transformation, Ifeoma navigates Eugene's autocratic patriarchal manly guard of his family by exploiting his religious fanaticism as she puts it: "After all, I had to use a pilgrimage to Aokpe to get him to say yes to the children's visiting us" (p.145). The Virgin Mary is purported to have appeared in an apparition at Aokpe and many Christians are trekking there to have a view of it. Eugene therefore finds it worthy to allow his children to go on the pilgrimage to Aokpe, oblivious of the fact that it is Ifeoma's strategy to have uncontrolled access to the children. By outwitting Eugene this way, Ifeoma shows confidence, competence and ingenuity.

Earlier in the novel, Beatrice indicates that she endures her husband's physical abuses because she has nowhere to go and fears other women taking over her marriage (p.255).It is Ifeoma's anger and trivialization of Beatrice's patriarchal concerns about polygamy that re-assert her own subjectivity as she retorts: And so? I ask you - and so? (p.255). In addition, Ifeoma's economic independence seem to enforce her selfhood as opposed to Beatrice who is financially dependent on her abusive husband (p.103). Her ability to steer her family along the daily drudgeries of insufficiency and yet hopefulness is a remarkable demonstration of feminist agency. Adichie thus suggests that female economic independence is an integral variable in the realization of female subjectivity. Thus once Beatrice identifies a means of circumventing the impediment to her subjectivity by poisoning her husband, without losing out on her financial supply, she takes full advantage of it (p.290). Ifeoma then becomes a womanist agentic inspiration in the liberation of a fellow woman from sexual and physical subjugation. 
Hollist's Finaba also demonstrates subjectivity and agency in her show of power and control over her sexuality as she aged and grew in experience in So The Pa Does Not Die. Even as a child she agrees to the initiation rites which includes female circumcision not because she does not know it is painful and risky (p.6). She longs for the rites because she wants to 'belong', to be called a 'proper woman' and that is the only way she knows how (p.4). Remarkably, African women's peculiar womanist characteristic of communalism, the sense of 'we' feeling, is highlighted in the way Fina is mentally ready to become an indispensable member of her community regardless of the pain she has to endure. At that tender age it is a show of subjectivity to be decisive in thought and inclined to obtaining what she desires (p.6).Fina, from childhood, has the knowledge that sometimes one pays a price to obtain what one desires. To desire initiation and to submit to painful processes of knowing her 'self' is an evidence of Fina's control and power over her 'self' and her desires. It is an evidence of the evolution of her subjectivity.

Fina's subjectivity also evolves when she encounters Sidebe Kakay, the diamond dealer, later in life. Sidebe becomes the first litmus test of her earlier resolve to do the right thing: "The first test of that resolve came a short week later on the day she met powerful and handsome Mandingo merchant, Sidebe Kakay" (p.55). Sidebe already has three wives but wants Fina as a fourth (p.61). First it takes Sidebe pleading for fifteen minutes to get Fina to let him in into her apartment (p.58). Even when he is finally allowed in, he exerts himself to his limit to get Fina to agree to his proposal without success: "... but unused as he is to exerting himself for anything, he feels he has expended too much time and energy on this sapling of a woman" (p.59). Sidebe's description of Fina as a 'sapling' connotes his patriarchal disregard for her. Fina, therefore, proves to Sidebe that not all African women can be taken for granted; certainly not the new generation of African women who know their rights and insist on them.

African Womanism, as already discussed, requires mutual respect between men and women for gender co-operation. Fina therefore, as a womanist, asserts her right to Sidebe's masculine respect for women and their sexuality. Through Fina's strong character showing, Hollist criticizes the trivialization and commodification of African women's body as she counter's the claim that African women are incapable of averring subjectivity.

Fina's experiences with Sidebe happen after she suffers humiliating slurs in her foster home (p.21) and also from colleagues in college (p.37). it also happens after she is sexually violated by her college professor (p.48). Despite all these repressive treatments, Fina proves agentic and indomitable. The defaming experiences she goes through as part of her growing up rather empower her to later tower above Sidebe's incessant advances. This explains her resoluteness in doing the right thing (p.55). Hollist, therefore, suggests that African women may be experiencing very repressive conditions in their quotidian lives but through Fina, he lays the claim that such conditions breed respectable toughness and smartness as epitomes of agency and subjectivity. Through Fina's show of womanist scruples, Hollist is able to counter the pervasive literary denial of African women's assertiveness.

Fina's subjectivity also evolves later in America whiles in a relationship with Cammy. On several occasions, when the two discussed an issue, Hollist presented Fina as an active and self-confident yet cooperative partner. For instance, she indicates her interest in reconciling with Cammy after their wedding falls apart in the church (p.154). However, when Amman, her African American friend suggests that she calls Cammy and 'sort out' with him, Fina insists that she, Fina, will never beg a man to marry her as she puts it: "That I will not do. Never! I'm not going to beg him to marry me. If he wants me, he is gonna have to run right back to me, wherever I may be, the same way he run away. So let's not talk about him anymore, okay?" (p.161). Here, as a womanist, Fina is assertive in the face of depression. She also exhibits womanists' power and ability to position themselves as equal partners and not subordinates. Though she weeps bitterly because of the humiliation of the disrupted wedding (p.151), Fina recovers quickly (p.162). Hollist, therefore, advocates egalitarianism through Fina's insistence on Cammy's respect for her. As a womanist, Fina feels slighted by Cammy's abandonment when their wedding is disrupted by an intruder but she eventually gets Cammy to apologize: "Fina, I'm truly very, very, very sorry for what happened today... (p.179). Hollist, through Fina's scrimmage with Cammy, resists the supposition that African women are passive and subordinated and incapable of subjectivity in gender relativities.

Another instance where Hollist showcases Fina as an assertive African woman is when Fina insists on when and how to have sex with Cammy. Prior to their failed wedding, Cammy attempts to have sex 
with Fina with the lights on (p.105). This also happens just after the two have a discussion on female genital mutilation (p.98). In that heated discourse, Fina is supportive of cultures that practice female genital mutilation. In addition, she announces that she is circumcised (p.104). The announcement stuns Cammy who thinks his instincts were right (p.104).Hollist uses Fina's revelation of her circumcision as a platform for the demonstration of Fina's subjectivity in the novel. The revelation incites Cammy's curiosity just as it propels the evolution of Fina's assertiveness. Thus it so happens that Cammy proposes marriage to Fina after Fina's disclosure that she is circumcised. Subsequent to the proposal, later that night as the two slept together, Cammy clandestinely tries to put on the light in order to have a peak at Fina's circumcision cut. Fina tables a strong repulsion as she feels disrespected. In order to insist on Cammy's respect for her body, Fina does not let him have his way (p.105). There is evidence of a self-confident Fina whose valour proves both Cammy and critics who call African women unassertive wrong. Thus, in response to Cammy's surreptitious request, Fina shows agency by reading in-between the lines before Cammy's hands could reach the lamp to turn it on (p.105). She holds his hand to a halt and insists that she does not want to have sex when the lights are on. Therefore, try as Cammy did, he is unable to overturn that ruling. Fina's insistence on her right to her body is evidence of her subjectivity.

On another occasion, we have the opportunity to witness Fina in an agentic and assertive mood. This time, she re-emphasizes her assertiveness when Cammy tries again to stealthily see her circumcision cut. This time she is emphatic on the fact that Cammy's proposal does not give him the right to objectify her body (p.105). As a result, she abruptly ends their sexual intimacy at the very instant that Cammy turns on the light. In addition, according to the narrator, she bursts out with ferocity as she vehemently registers her ire:

He [Cammy] even secretly installed a clap-activated lamp in his bedroom and once. As Fina relaxed expectantly, he pulled back and clapped. Lights engulfed the room, but Fina's reaction would have been the envy of any U.S. Navy Top Gun. Before he could see the object of his subterfuge, she had ejected herself from between his legs and from the bed. "You bastard" she shouted (p.105)

Through Fina's assertive repulsion above, Hollist demonstrates African women's subjectivity in the novel. After Fina yells at Cammy for trying to sneak on her, Cammy retorts by questioning why a man cannot see the nakedness of his wife (p.105). It is in Fina's response that Hollist again, demonstrates the new generation of African women's assertiveness. In the excerpt below, Hollist emphasizes Fina's response to Cammy's attempt to take her body for granted because he has proposed marriage. Present in this response is Hollist's effort to draw our attention to the womanist quest for co-operation between genders and respect for each other's rights. The idea that when a woman marries a man, the woman loses her right to her 'self' is debunked by Hollist through Fina's reaction to Cammy's quest below:

Come on Fina, ah fed up with all this foolishness! A man can't see his wife? I am not your wife. And your need to see gives you the right to play games when I say I don't want to do something? What do you want to see? You. Ah want to see de front! No you want to examine me, like one of patients. Maybe ah do. Wha' wrong with that? Look, I'm just not ready for that yet. I don't want to become an object for you to study... Maybe it is cultural, but I just can't (p.106)

From the above, Hollist demonstrates Fina's womanist maturation in the way she resists the commodification of her body. Fina's agency and individuation manifests in her ability to alter the patriarchal assumption of ownership of a woman because of marriage demonstrated by Cammy. Another hegemonic patriarchal postulation here is that the body of females can be commoditized with the promissory of marriage. Hollist's characterization of Fina, as a result, projects the autonomy of African women. Hence through Fina's decisiveness, on when and how she wants to have sex with Cammy, evident in her emphatic "I can't" (p.106), Hollist efficaciously rebuffs the hegemonic patriarchal practice that trivializes the female body. He unequivocally, indicates that the idea of compromise in a relationship is not only a demand on women but on both genders.

Another interesting means by which Hollist unveils African women's subjectivity and agency in the novel So The Path Does Not Die is not by demonstrating Fina's own agency but by characterizing Fina as an agentic medium. As an agentic medium, Fina becomes a catalyst for the evolution of another's agency. This is similar to Adichie's strategic use of Ifeoma in her novel Purple Hibiscus. In 
that novel, Ifeoma forefronts the womanist transformation of Beatrice and her children from the den of patriarchal oppression to the experience of true emancipation. In Hollist's novel, Fina plays a similar role by mediating the enlightenment of the world on the essence of female genital mutilation as a traditional practice and why she relocates to it. Cammy as the gatekeeper of modernity is juxtaposed with 'darkness' as an imagery of hegemonic traditional practices for which Fina serves as a custodian. Hollist's characterization of Fina as a medium of agency for the transformation of suppressive traditional cultures is thus indicative of Fina's womanist maturation. Initially, as indicated earlier in this paper, Fina refuses to let the lamp on to reveal the nature of her circumcision cut. This metaphorically speaks to her refusal to accept the need to expose the harmful nature of the practice as part of the campaign to end it or at least modify it. Thus Fina's final decision to return home to help modify female genital mutilation as a traditional practice marks her agentic evolution. Her innate drive to reach out to other women who have suffered the painful effects of female genital mutilation, to help them to recover from their pain and to educate the traditional gatekeepers in Sierra Leone on the effects of female genital mutilation makes her a womanist medium with the power to manipulate her social order (p.185). Fina's show of strength knowledge and sense of communal responsibility incites Cammy's exasperating comment of admiration: "Oh Fina, I don't know what to say, I don't deserve you..." (p.186).

Fina's thoughtfulness about her community back home in Sierra Leone reminds me of Ogunyemi (1985) when she posits that for an African woman to be a womanist, she must seek the welfare of her community. Seeking the wellbeing of others in a community positions Fina in a humanistic locus (Heffner, 2014). It is on this bases that I think Hollist also presents both Nabou and Baramusu as agentic women who show unflinching commitment to the nurturing of their communities.

Nabou is Fina's mother whose first daughter dies after the latter completes her initiation rites. Nabou believes that "The path we follow in cutting is wrong" because that killed her first daughter (p.3). Baramusu, on the other hand, is Fina's paternal grandmother who believes that an uncircumcised woman is on the wrong path of life (p.3). Both women want the best for Fina but from different standpoints. Nabou pursues the modernist liberal womanist nurturing approach by insisting that Fina attends school, gets a good job marries and have children without going through female genital mutilation that may kill her like it did to Dimusu (p.2). Dimusu is Nabou's first daughter who died after being circumcised during her initiation (p.3). On the other hand, Baramusu wants Fina to undergo female genital mutilation as a path to womanhood. She believes that the initiation rites teaches a woman how to become a good wife and how to take care of her home as a wife (p.2). Both women achieve agency because they are able to influence society with their ideologies. Fina's experience of circumcision contributes to the many disagreements she has with Cammy (p.99). She even blames her failed wedding extensively on the curses the village folks of Talaba pronounce on her and her family when her parents stall her initiation rites (p.151). To a similar extent, Fina blames her rape experience with Kizzy and her abusive experiences with Jemal on the path her parents chose for her (p.152). In both ways, Baramusu and Nabou manipulate Fina's life and our own perception about life. Once again, Hollist demonstrates African women's agency by empowering these two women as stimuli for change in their worlds through the power of their knowledge.

\section{CONClusion}

As indicated earlier, subjectivity as used in this paper amounts to ability to generate knowledge and being able to alter one's environment through the power of this knowledge. Agency is therefore used as a term that refers to the ability to successfully manipulate one's environment through the exhibition of one's subjectivity. Though Grosz (1994) and others discount women in general's ability to attain and exhibit agency and subjectivity, Adichie, Hollist and Shaw in Half of a Yellow Sun, Purple Hibiscus, So The Path Does Not Die and Redemption Road indicate otherwise. The novels therefore demonstrate the enterprise and assertiveness of their Africa women characters. As third generation West African novels, these novels convincingly show that there are impediments to the evolution of African women's agency and subjectivity. However, African women have the navigational competence that enables them to attain and demonstrate subjectivity and agency. The ability of women like Fina, Bendu, Ifeoma, Kainene, Olanna and Beatrice, amongst others, to survive, navigate, and guide other women to meandre the curves of patriarchal hegemony in the examined selected texts is an attestation to African women's agentic and assertive potentialities. 


\section{REFERENCES}

[1] Bachrach, P.\& Baratz, M. S. (1962). "Two faces of power". American political science review, 56(04), 947 952. Cambridge: CUP

[2] Chakravarty, R. (2007). Feminism and contemporary women writers: Rethinking subjectivity. New Delhi / London: Routledge.

[3] Fonchingong, C. C. (2006). "Unbending gender narratives in African literature". Journal of International Women's Studies, 8(1), 135-147.

[4] Grosz, E. (1994). Volatile Bodies: Toward a Corporeal Feminism. Indianapolis: Indiana University Press.

[5] Kandiyoti, D. (1993). Identity and its Discontents: Women and the nation, colonial discourse and postcolonial theory. Hertfordshire: Harvester Wheatsheaf Campus.

[6] Laqueur, T. (1986). "Orgasm, Generation, and the Politics of Reproductive Biology." Representations, CA: University of California Press.

[7] Mokakha, A. G. (2014) "Portrayal of the African Woman in Half Of A Yellow Sun", Research in Peace, Gender and Development, Online: interesjournals.org/JRPGD

[8] Ogunyemi, C. O. (1985).Africa Wo/Man Palava: The Nigerian Novel by Women (Women in Culture and Society Series). Chicago: Published by University Of Chicago Press

Citation: Juliana Daniels. "Female Agency and Subjectivity in Some Selected West African War Novels". International Journal of Humanities Social Sciences and Education (IJHSSE), vol 5, no. 3, 2018, pp. 112-123 doi: http://dx.doi.org/10.20431/2349-0381.0503012.

Copyright: (C) 2018 Authors. This is an open-access article distributed under the terms of the Creative Commons Attribution License, which permits unrestricted use, distribution, and reproduction in any medium, provided the original author and source are credited. 